\title{
Internationalization of Medical Education-a Scoping Review of the Current Status in the United States
}

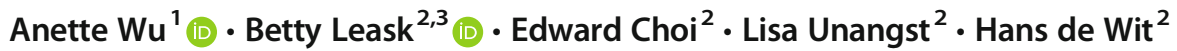 \\ Published online: 5 August 2020 \\ (C) International Association of Medical Science Educators 2020
}

\begin{abstract}
This article explores the current status of internationalization of medical education in the United States. Dominant themes of articles published from 2000 to 2018 indicate that common formats are institutional partnerships, international learning at home, and student mobility programs. Critical analysis on the basis of internationalization of higher education, recommendations, and future perspective is given.
\end{abstract}

Keywords Internationalization $\cdot$ Medical education $\cdot$ Medical school $\cdot$ Literature review $\cdot$ Curriculum

\section{Introduction}

In the last 25 years, the internationalization of higher education (IoHE), which includes internationalization of the curriculum, has emerged as a dynamic field of study supported by a rich body of scholarly literature and research. The consensus is that internationalization of the curriculum, referring to the incorporation of international, intercultural, and global dimensions into the curriculum in ways that are relevant to graduates' professional practice [1], is important for all students. While motivations for internationalization of individual higher education institutions are varied, including quality improvement, provision of access, competitiveness, growth, and financial profits [2], the provision of a professionally relevant education that prepares all students to be interculturally proficient professionals and citizens is the responsibility of the disciplines [3-5].

Anette $\mathrm{Wu}$

aw2342@caa.columbia.edu

1 Department of Medicine and Pathology and Cell Biology, Vagelos College of Physicians and Surgeon, New York, NY, USA

2 Center for International Higher Education, Lynch School of Education, Boston College, Boston, MA, USA

3 School of Education, La Trobe University, Melbourne, Australia
In medical education, this might mean, for example, developing students' ability to access and evaluate new ideas and practices from diverse national and cultural sources, using advanced intercultural skills in their professional practice, and practicing medicine in a global context.

Recent global health events, namely the Ebola virus, SARS, or COVID-19 pandemic, have demonstrated the need for efficient international collaboration and communication in biomedical research, education, and patient care. Such global health emergencies require efficiency in international communication, culturally competent and expert healthcare leadership (locally, nationally, and internationally), rapid international public health action, and collaborative international biotechnology and medical science research. Today, more than ever before, these elements are not optional choices but rather represent essential components that should be included in medical education curricula in all parts of the world.

In this context, it is important to take stock of where we are and where we might want to go next in the internationalization of medical education (IoME), using research that has been undertaken into IoHE curriculum, teaching, and learning, tailored to the needs of the medical profession. The authors argue that this offers a useful way forward because it focuses attention on preparing all medical graduates to meaningfully contribute to society as professionals who practice locally but are also global citizens. 


\section{Internationalization of Medical Education-Definition}

To date, IoME is a broad term with no formally agreed upon definition. For the purpose of this paper, we utilize a definition commonly used in research on IoHE and apply it to medical education. Thus, we define IoME as the process of purposefully integrating international, intercultural, or global dimensions into medical education in order to enhance its quality and prepare graduates for professional practice in a globalized world. This definition is consistent with research-based and frequently cited definitions of higher education internationalization [6], internationalization of the curriculum, and internationalization at home frequently cited in the literature on higher education [6-8]. It constructs IoME as a concept that includes intentional, systematic, and evidence-based activities designed to ensure students achieve specific learning outcomes through engaging in high-quality learning experiences. It positions IoME as a means to a specific international educational goal, not a goal in and of itself.

\section{Public Health, Global Health, International Health, and the Goals for Internationalization of Medical Education}

Educational goals and competencies for IoME overlap with other subject matter taught in medical school (i.e., cultural competency). In recent years, Public Health (PH) and Global Health (GH) have become an important part of medical curricula, incorporating elements of social equity, diversity, inclusivity, and cultural competence into medical education. In order to differentiate these different terms, short definitions are provided below.

$\mathrm{PH}$ is regarded as "...the science and art of preventing disease, prolonging life, and promoting health through the organized efforts and informed choices of society, organizations, public and private communities, and individuals..." [9]. $\mathrm{GH}$ as its global counterpart historically evolved from International Health - an area that addresses local, national, and international health concerns on all levels [10]. While both terms still exist, GH was defined by Koplan in 2009 as “... an area for study, research, and practice that places a priority on improving health and achieving health equity for all people worldwide..." [11]. Based on Koplan's initial definition, others have proposed a shorter definition - "collaborative trans-national research and action for promoting health for all" [12]. There is still ongoing debate on a commonly agreed upon definition [13] and there is inconsistency in the way medical educators use the term GH. GH is frequently conceived as a multidisciplinary field of service, research, and education undertaken as part of an altruistic "Global North to Global South" collaboration, and/or as part of a national/local health equity program. Its primary goals - as it oftentimes appears in published work-are to improve the health of underserved individuals and populations, and to achieve health equity for all people worldwide, with a primary focus on the resource-poor abroad [14].

For medical education, GH education programs in the in low- and middle-income countries (LMICs) are frequently used to report on the internationalization of the medical curriculum - mostly to describe extracurricular activities or projects in LMICs or the underserved populations. Thus, the enactment of GH in medical education programs appears to be narrower and more limiting than the definition of GH itself suggests.

While there is overlap with the broader definition of $\mathrm{GH}$, IoME should not be equated with GH. GH-as the broader term suggests - includes the vision of improvement of health for all people worldwide. In contrast, IoME is an area of educational science, an educational concept, a framework, and a means to develop international and intercultural learning outcomes in all students. Despite their value as a means of internationalizing the learning outcomes of some students, GH programs - particularly its narrower term - should not be a proxy for the modern concept of IoME. Goals and outcomes set by GH (i.e., the improvement of health for all people worldwide) are considered the ultimate goal for IoME. Thus, IoME is a means to achieving this ultimate goal, and includes the acquisition of cultural competency and knowledge about health issues worldwide.

IoME encompasses the international collaborative goals and dimensions between nations and does not solely focus on cultural differences. IoME can play an important role by preparing future physicians to practice medicine in a global context and laying the framework for international collaboration and understanding of differences among nations. IoME includes, but is not limited to, learning about and understanding differences in international healthcare education, healthcare delivery systems, health economics, health ethics, and health laws; building international peer networks; and providing future physicians with skills in intercultural competencies, collaboration, and international leadership.

IoME can therefore improve the practice of future physicians by purposefully developing students' understanding of international social, cultural, economic, and ethical differences in healthcare, and by supporting better communication, fostering international leadership, collaboration, and understanding. IoME creates awareness building of the importance of these differences regarding patients and healthcare, and creates physician feelings of being part of a global medical world.

One can argue that IoME highlights meaningful differences between individual nations with the goal of international understanding and improvement in healthcare, whereas GH issues transcend individual nations. IoME is a means to improve $\mathrm{GH}$, leading to a globalized and better healthcare world. 
Hanson [15] describes three different models of IoME drawing on literature from 1992 to 2010. The "market model" focuses on competition for students internationally and positioning of academic institutions in the global market. Hanson argues that this approach, focused on revenue growth, market consolidation, and fiscal returns rather than educative outcomes, typifies the US approach to internationalization. In contrast, the "liberal model" focuses on the promotion of international and intercultural understanding and cooperationintroduced for international higher education in the postWWII era. Curricula in this model might prepare students to work in international or diverse cultural settings, or to be future global collaborators through exchange. The third "social transformation model" emphasizes cross-cultural understanding operationalized "in a spirit of mutuality and reciprocity, through networks or partnerships." Hanson argues that this model is the one most closely aligned with approaches to current international practices in medical education.

IoME necessarily involves multiple players - students, faculty, medical professionals, medical educators, administrators, institutions, and governments [16]—and includes curricular components such as content, pedagogy, assessment, and learning outcomes. The key players include students, for whom IoME may involve didactic lectures in the classroom ("IoME at home"), peer-to-peer connections and networking, intercultural experiences in clinical settings, outbound mobility activities, and inbound mobility including international student recruitment. Other key players are faculty, for whom IoME involves research, teaching, and service. And finally, the academic institutions as major stakeholders, who play a significant role in initiating and orchestrating these international endeavors.

\section{Internationalization of Medical Education in the US-Goal of the Study and Its Importance}

Stutz et al. [17] highlighted the paucity of contextualized national studies on the topic of internationalizing the curriculum in medicine. This is concerning, given the myriad varieties of professional practice, and the impact of our globalized world on local medical practice.

The overall goal of this study was to evaluate the current status of IoME in the United States (US) by capturing scholarly work on IoME in the published literature.

The aims were to distill what is being reported and how, and to assess whether more educational research in this area is needed. Identifying gaps and limitations in reporting can help IoME moving forward as an area of investigational research for the medical educator community.

The authors addressed the following question: "What is the current status of scholarly work on the internationalization of medical education in the United States?"
Intentionally, the authors avoided searching non-scholarly work such as websites or surveyed institutions for international educational curriculum elements or programs.

In order to find a way forward, this article summarizes USbased reports on programs, including $\mathrm{GH}$ programs at medical schools, discussed over the last 18 years in peer-reviewed journals. The authors focus their discussion on didactics and formats of programs and reasons for gaps in the literature. It provides a picture of the evolving conceptualization and practice of the internationalization of medical education as it is commonly understood and compares this with contemporary approaches to IoHE curriculum that have evolved over a similar period of time. The comparison informs suggestions for future approaches to IoME.

\section{Materials and Methods}

A scoping review was undertaken to identify what has been published on IoME in US medical schools. The purpose of this scoping review was to provide an overview of current approaches.

The review was conducted in several steps [18]: identify the research question, identify relevant studies, study selection, chart the data, and summary of results.

\section{Research Question}

The research was undertaken to answer the question "What is the current status of scholarly work on the internationalization of medical education in the United States?"

\section{Identification of Studies}

A scoping review was conducted using a literature search in Medline, Pubmed, Google Scholar, and EBSCOhost. Searches targeted the date range from January 1, 2000, to August 1, 2018.

This task was performed by an interdisciplinary team consisting of a medical educator, researchers in internationalization, and research assistants in international higher education, from diverse linguistic and cultural backgrounds, working at two major US institutions.

The search included keywords, titles, and abstracts of studies from the databases listed. The search terms/keywords or phrases used for this review were as follows: "international," "medical," "education," "United States," The Boolean operators "OR" and "AND" were used to expand and narrow the searches to include all the pertinent publications within the period indicated above.

The following limitation was encountered when using a combination of these keywords. For example, a search in PubMed exceeded 180,000 articles. To narrow down the 
results, an advanced search included the term "curriculum," resulting in over 170,000. Since this did not represent a significant reduction of results, the keywords "medical school" and "training" were added.

Albeit not a term the authors were intending to include initially, "global" was added, resulting in about 46,000 results. Adding "USA" or "United States" resulted in about 29,000 hits. Combining with "internationalization" and "internationalisation," the search resulted in 77 or 29 articles respectively. None of the articles was deemed appropriate for the intended search as they included other health professions or were not relevant for medical education.

Given the paucity of the initial search pairing, the authors decided to focus on scanning titles and abstracts. Overall, searches using the keyword combinations below were effective in returning a moderate quantity of articles with topic relevance. The authors avoided the term "global health" in the search (1) to not limit the searches to global health education, and (2) to not mix key terms that have different meanings. When hand-searching individual articles, crossreferencing articles that were not found in the initial search were added to supplement the list.

PubMed - The keywords "international AND medical AND education AND United States" resulted in a total of 6563 articles using a filter for journal articles inclusive of reviews and systematic reviews. A title and abstract search was then conducted.

Similar to the PubMed searches, the queries in Google Scholar, EBSCOhost, Medline, and Web of Science combining the keywords returned too many results. This limitation was addressed by narrowing the search parameters to scanning article titles, which provided published works with a primary focus on IoME.

The purpose of our scoping review was to provide an overview of current approaches to IoME. As IoME as a research field itself is not formally defined and still evolving, modification and adjustment of keywords used in the searches were necessary in order to capture all relevant articles.

\section{Selection of Relevant Studies}

Based on a title and abstract scan, the relevant studies were compiled into a master spreadsheet of 219 non-duplicate articles. This spreadsheet including title and abstracts was reviewed independently by the authors (A.W., E.C., L.U.) and as a group using a set of inclusion and exclusion criteria.

Criteria for inclusion comprised any articles that reported on international activities and/or programmatic efforts for US medical students. Those included, but were not limited to, journal articles of (1) original research, (2) case reports, (3) reviews and systematic reviews, (4) descriptive articles, and (5) program overviews.
Exclusion criteria were as follows: (1) articles written in non-English language, (2) articles about programs in nonUS institutions (unless collaborating with US institution on IoME, (3) articles describing international postgraduate (residency) training, (4) reports on international students at US medical schools or foreign medical graduates, (5) international comparisons of medical curricula, (4) opinions/OpEd on IoME, (5) work reporting on offshore US academic institutions or US institutions supporting other nations in building medical curricula/schools, (6) studies from other allied health professions (nursing, dentistry, public health, pharmacy, social work, emergency medicine technician, biomedical sciences, or veterinary medicine), and (7) reflective pieces, book reviews, or commentaries.

This narrow screening was deemed important to identify relevant articles on IoME and to answer the research question on the current status of, and approaches to, IoME in the US.

Cross-references in identified review articles were only included when deemed appropriate for the purpose of the study.

Based on this screening, the authors indexed each article according to the extent to which it met the inclusion/exclusion criteria, resulting in 49 articles selected for intensive study. Figure 1 depicts our methods for choosing articles for this study.

\section{Data Charting}

A total of 49 articles over a span of 18 years were identifiedsorted by author, publication year, location, sample, method, major findings, discussion points, and limitations (Table 1).

\section{Summary of Results}

Despite this relatively low count, we found a diversity of internationalization efforts described, including narratives of individual international experiences [42], research on student initiatives [61], description of single school programs [24, 25, $37,43]$, institutional partnerships [24, 25, 67], cultural learning at home [21,30], reviews on school websites [54], and international GH programs $[32,51]$. As the goal of the study was to determine the current status of IoME in the US via viewing of published literature, the authors identified three overarching themes that summarized the articles, to help in identifying current practices in IoME-institutional partnerships, international learning at home, and student mobility programs. Definition of each category below is based on descriptions found in IoHE [68]:

Institutional Partnerships Articles that described programs in which US academic institutions and medical schools partnered with one or more schools or programs outside of the country to provide elements of IoME to medical students 


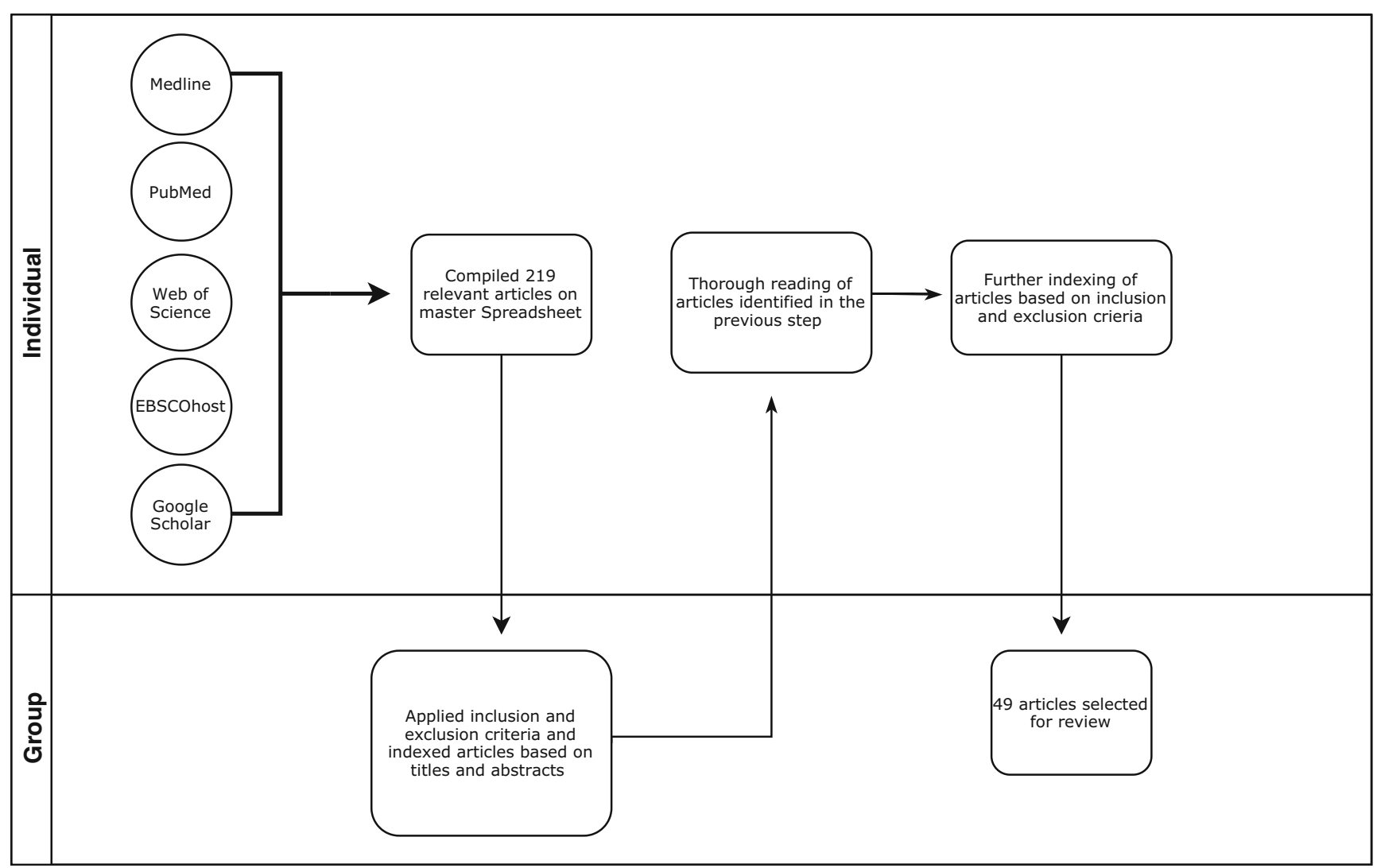

Fig. 1 Methodology of searches

were listed in this category. In the majority of the articles, these partnerships were formed with low- and middleincome countries (LMICs).

Internationalization at Home Studies that contained information on international learning and exposure of medical students to either global content or international courses or formats within their school curriculum (at home) fell into this category. Studies that included students' pre-departure training for site visits were included.

Student Mobility Programs Programs describing study abroad, international medical service missions, clinical electives, or short-term rotations were included in this category. Many, if not the majority, of the programs described student outbound mobility. While often these studies were part of activities organized via institutional partnerships, some that report trips that were self-organized by students and individual faculty members are included.

\section{Institutional Partnerships}

With few exceptions, most described reports focused on partnerships between US schools and institutions in the LMICs, the majority in South America and Africa
[25-27, 37, 41, 56, 60, 63, 67], and some in South East Asia [34, 49]. Rybak described a partnership with the Ukraine [56], and there were two reports of the same partnership with Israel [26, 27]. The described partnerships with LMICs originated from only nine US medical schools, with some schools reporting on multiple occasions, such as Brown University or SUNY [24, 25, 53, 57, 58, 60]. The report by Finkel et al. in 2006 was the only article found that reported on partnerships solely with European schools [29]. Ip et al. do not mention formal partnerships with Japan and Germany, but student exchanges at Brown University were administered via an official exchange program; so there is an assumption that a partnership was in place [60].

International institutional partnerships appear to be a common activity associated with the IoME, although partnership strength and impact varied greatly. At one end of the scale; formal institutional partnerships were reported "for show" $[37,56,63,66]$, while at the other end of the scale, they are mentioned as part of other reports on IoME activities without further details [39, 55, 62].

Overall, there was a full range of number of partners reported, including schools partnering with multiple partners $[24,25,29,46]$, whereas others report on one specific partnership only $[37,56,62,63,66]$. While many more international partnerships may exist, they appear not to 
Table 1 List of articles

\begin{tabular}{|c|c|c|c|c|c|}
\hline Author & Year & $\begin{array}{l}\text { Institutional } \\
\text { partnership }\end{array}$ & $\begin{array}{l}\text { Internationalization } \\
\text { at home }\end{array}$ & $\begin{array}{l}\text { Student } \\
\text { mobility }\end{array}$ & Major findings/type of report \\
\hline Haq, C. [19] & 2000 & & $\sqrt{ }$ & $\sqrt{ }$ & $\begin{array}{l}\text { Study on outcome research of } 3 \text { US medical } \\
\text { schools - to LMIC as part of an exchange } \\
\text { program, } 6-8 \text { weeks, plus 2-week prepara- } \\
\text { tion }\end{array}$ \\
\hline $\begin{array}{l}\text { Esfandiari, A. } \\
\quad[20]\end{array}$ & 2001 & & $\sqrt{ }$ & $\sqrt{ }$ & $\begin{array}{l}\text { Follow-up report on } 52 \text { student alumni from } \\
\text { tropical medicine electives (including } \\
\text { 2-week classroom work)-Drew University } \\
\text { to several LMIC. } 2 / 3 \text { continued international } \\
\text { work as graduates }\end{array}$ \\
\hline $\begin{array}{l}\text { Griswold, K.S. } \\
\text { [21] }\end{array}$ & 2003 & & $\sqrt{ }$ & & $\begin{array}{l}\text { Program description of 2-year study on medica } \\
\text { students working with refugees. Outcomes } \\
\text { includes cultural competency }\end{array}$ \\
\hline Godkin, M. [22] & 2003 & & & $\sqrt{ }$ & $\begin{array}{l}\text { Outcome research on effect of international } \\
\text { electives on medical students }\end{array}$ \\
\hline $\begin{array}{l}\text { Thompson, M.J. } \\
\text { [23] }\end{array}$ & 2003 & & & $\sqrt{ }$ & $\begin{array}{l}\text { Review of international health electives; } \\
\text { positive outcomes }\end{array}$ \\
\hline $\begin{array}{l}\text { Imperato, P.J. } \\
\text { [24] }\end{array}$ & 2004 & & $\sqrt{ }$ & $\sqrt{ }$ & $\begin{array}{l}\text { Summary report of } 25 \text { years of single-center } \\
\text { experience. SUNY with Kenya, India, } \\
\text { Thailand, and other LMIC. Objectives } \\
\text { outlined }\end{array}$ \\
\hline $\begin{array}{l}\text { Jotkowitz, A.B. } \\
\text { [26] }\end{array}$ & 2004 & $\sqrt{ }$ & & & $\begin{array}{l}\text { Report on partnership between Columbia } \\
\text { University and Ben Gurion University, } \\
\text { Israel; US students and Israeli students }\end{array}$ \\
\hline $\begin{array}{l}\text { Margolis, C. } \\
\text { [27] }\end{array}$ & 2004 & $\sqrt{ }$ & & $\sqrt{ }$ & $\begin{array}{l}\text { Report on partnership between Columbia } \\
\text { University and Ben Gurion University, } \\
\text { Israel; US students and Israeli students }\end{array}$ \\
\hline
\end{tabular}

A 4-7-year follow-up of program participants after 6-8-week elective and prep course in LMIC, via International Health Fellowship Program. Long-term outcome (67\% in community health and $57 \%$ in international work)

Finkel, M. [29] $2006 \sqrt{ }$

Griswold, K.S. 2006 [30]

Smith, J.K. [31] 2006

Drain, P.K. [32] 2007

Houpt, E.R. [33] 2007 $\sqrt{ }$

$\begin{array}{ll}\text { Ly, E. [34] } & 2007 \\ \text { Mao, J. [35] } & 2007 \\ & \\ \text { McKinley, D. } & 2008 \quad \sqrt{ } \\ {[36]}\end{array}$

Student exchange program, including work on comparative healthcare. Partnerships of Cornell-Weill, Harvard, and Dartmouth, with schools in Germany, Sweden, and Denmark

Medical students working at home with international refugees. Learning outcomes includes cultural learning

Report of University of Texas preclinical medical students - to Nicaragua 1997-2005

Summary of reasons why, and suggestions of how GH can be integrated into medical school curricula

Summary of recommendations of competencies for global health education for US medical students

Case report from Brown University medical student in Cambodia

Outcome on cultural sensitivity for medical students after 4 weeks, acupuncture course in China. Some junior students

Study on online survey/questionnaire of 96 US medical schools that offer international
Limitations

1995 to 1997 ; students' perceptions only

Data from 1987 to 1998. Very brief report without further details

US and Canadian medical students and residents

Limited information on outcome research; same program as Bruno [25]

Students are enrolled in Israel; same program as Margolis [27]

Not short-term exchange experience. US students are enrolled in Israel; same program as Jotkowitz [26]

Participants from 1995 to 1997, 39 responses; same program as Haq [19]

Descriptive report, limited to 12 students per year; no outcome data

Outcome research based on students' perceptions

Limited to global burden for disease, traveler's health, immigration health

One student only

Small study of 18 students from several US schools reported 
Table 1 (continued)

\begin{tabular}{|c|c|c|c|c|c|c|}
\hline Author & Year & $\begin{array}{l}\text { Institutional } \\
\text { partnership }\end{array}$ & $\begin{array}{l}\text { Internationalization } \\
\text { at home }\end{array}$ & $\begin{array}{l}\text { Student } \\
\text { mobility }\end{array}$ & Major findings/type of report & Limitations \\
\hline & & & & & $\begin{array}{l}\text { experiences at US medical schools. Almost } \\
\text { all schools have some international offer- } \\
\text { ings. High variability of international op- } \\
\text { tions found }\end{array}$ & \\
\hline Cohn, J. [37] & 2010 & $\sqrt{ }$ & & $\sqrt{ }$ & $\begin{array}{l}\text { Description of a partnership between } \\
\text { University of Pennsylvania and Botswana; } \\
24 \text { students sent per year }\end{array}$ & $\begin{array}{l}\text { Little information on } \\
\text { student activities; no } \\
\text { outcomes mentioned }\end{array}$ \\
\hline Vora, N. [38] & 2010 & & $\sqrt{ }$ & $\sqrt{ }$ & $\begin{array}{l}\text { Report on student-initiated preclinical elective } \\
\text { with learning objectives at Chicago Medical } \\
\text { School; with student placements in LMIC } \\
\text { and Europe (Armenia and Czech Republic) }\end{array}$ & \\
\hline $\begin{array}{l}\text { Chin-Quee, A. } \\
\text { [39] }\end{array}$ & 2011 & $\sqrt{ }$ & & $\sqrt{ }$ & $\begin{array}{l}\text { Surgery elective for medical students at Emory } \\
\text { University, in Haiti, } 1 \text { week }\end{array}$ & $\begin{array}{l}\text { Learning outcomes based } \\
\text { on general medical } \\
\text { skills and surgical goals }\end{array}$ \\
\hline Jeffrey, J. [40] & 2011 & & & $\sqrt{ }$ & $\begin{array}{l}\text { Literature review on outcomes of international } \\
\text { health electives at US medical schools and } \\
\text { career choices; quality of electives vary }\end{array}$ & \\
\hline $\begin{array}{l}\text { Landrigan, P.J. } \\
\quad[41]\end{array}$ & 2011 & $\sqrt{ }$ & & $\sqrt{ }$ & $\begin{array}{l}\text { General description of institutional global } \\
\text { health program and efforts at Mount Sinai } \\
\text { School of Medicine, including limited } \\
\text { student involvement around the world }\end{array}$ & $\begin{array}{l}\text { Very little reporting about } \\
\text { student activities; focus } \\
\text { on institutional } \\
\text { reporting }\end{array}$ \\
\hline $\begin{array}{l}\text { Anderson, } \mathrm{H} \text {. } \\
\text { [42] }\end{array}$ & 2012 & & & $\sqrt{ }$ & $\begin{array}{l}2 \text { case reports from students at University of } \\
\text { South Dakota after international elective }\end{array}$ & $\begin{array}{l}\text { Subjective cases by } \\
\text { students }\end{array}$ \\
\hline $\begin{array}{l}\text { Francis, E.R. } \\
\quad[43]\end{array}$ & 2012 & & $\sqrt{ }$ & & $\begin{array}{l}\text { Description of development of a student driven } \\
\text { global health elective/course at } \\
\text { Weill-Cornell Medical School }\end{array}$ & $\begin{array}{l}\text { Same program as Kulkarni } \\
\text { [44] }\end{array}$ \\
\hline $\begin{array}{l}\text { Goldner, B.W. } \\
\text { [45] }\end{array}$ & 2012 & $\sqrt{ }$ & $\sqrt{ }$ & & $\begin{array}{l}\text { Description of a non-clinical global health } \\
\text { course at Johns Hopkins University for } \\
\text { medical students with learning objective, } \\
\text { and peer exposure to students in the LMIC } \\
\text { (Uganda, Ethiopia) via videoconferencing }\end{array}$ & $\begin{array}{l}\text { Themes geared toward } \\
\text { clinical skills in LMIC; } \\
\text { exposure to LMIC only }\end{array}$ \\
\hline Holmes, D. [46] & 2012 & & & $\sqrt{ }$ & $\begin{array}{l}\text { Report on } 37 \text { students from the University of } \\
\text { Buffalo; for electives, with majority to } \\
\text { LMIC and } 4 \text { students to Europe (Ireland, } \\
\text { Switzerland, and UK). Details on activities } \\
\text { (clinical, research, language). Qualitative } \\
\text { and quantitative outcome research. }\end{array}$ & \\
\hline $\begin{array}{l}\text { Nelson, B.D. } \\
\text { [47] }\end{array}$ & 2012 & & $\sqrt{ }$ & & $\begin{array}{l}\text { Description of a non-clinical global topics } \\
\text { course at Harvard Medical School, to pre- } \\
\text { pare students and residents for work in low } \\
\text { resource countries }\end{array}$ & Focus on LMIC \\
\hline $\begin{array}{l}\text { Pallangyo, K. } \\
\quad[48]\end{array}$ & 2012 & $\sqrt{ }$ & & & $\begin{array}{l}\text { Description of partnership between Tanzania } \\
\text { and UCSF }\end{array}$ & $\begin{array}{l}\text { Student involvement } \\
\text { mentioned, without } \\
\text { further details }\end{array}$ \\
\hline Aldan, T.J. [49] & 2013 & $\sqrt{ }$ & & $\sqrt{ }$ & $\begin{array}{l}\text { Descriptive case report of } 3 \text { first-year medical } \\
\text { students from John Burns University- to } \\
\text { Micronesia }\end{array}$ & No outcome reporting \\
\hline $\begin{array}{l}\text { Cherniak, W.A. } \\
\text { [50] }\end{array}$ & 2013 & & & $\sqrt{ }$ & $\begin{array}{l}\text { Review on learning objectives for international } \\
\text { electives. Objectives include culture, } \\
\text { language, health systems, tropical medicine }\end{array}$ & $\begin{array}{l}\text { Not all were US medical } \\
\text { schools. LMIC only }\end{array}$ \\
\hline Khan, O.A. [51] & 2013 & & $\sqrt{ }$ & $\sqrt{ }$ & $\begin{array}{l}\text { Review on global health opportunities for US } \\
\text { medical students (courses and travel) }\end{array}$ & \\
\hline Leeds, I.L. [52] & 2013 & & & $\sqrt{ }$ & $\begin{array}{l}\text { Report on } 28 \text { students' experiences following a } \\
\text { 1-week surgical rotation at Emory } \\
\text { University, in Haiti }\end{array}$ & $\begin{array}{l}\text { Outcome study based on } \\
\text { students' perceptions } \\
\text { and clinical surgical } \\
\text { skills }\end{array}$ \\
\hline O’Connell [53] & 2013 & $\sqrt{ }$ & & $\sqrt{ }$ & $\begin{array}{l}\text { Description of AMPATH partnership between } \\
\text { Brown University and Kenya }\end{array}$ & $\begin{array}{l}\text { Student placement } \\
\text { mentioned, without } \\
\text { further details }\end{array}$ \\
\hline
\end{tabular}


Table 1 (continued)

\begin{tabular}{|c|c|c|c|c|c|c|}
\hline Author & Year & $\begin{array}{l}\text { Institutional } \\
\text { partnership }\end{array}$ & $\begin{array}{l}\text { Internationalization } \\
\text { at home }\end{array}$ & $\begin{array}{l}\text { Student } \\
\text { mobility }\end{array}$ & Major findings/type of report & Limitations \\
\hline $\begin{array}{l}\text { Peluso, M.J. } \\
\quad[54]\end{array}$ & 2013 & & $\sqrt{ }$ & $\begin{array}{l}\sqrt{ } \text { (as part } \\
\text { of the } \\
\text { reviewe- } \\
\text { d } \\
\text { pro- } \\
\text { grams) }\end{array}$ & $\begin{array}{l}\text { Review on structured global health programs } \\
\text { and courses at US medical schools; } 133 \\
\text { schools surveyed online, with } 32 \text { offering } \\
\text { global health programs. No standardization } \\
\text { found }\end{array}$ & \\
\hline $\begin{array}{l}\text { Rassiwala, J. } \\
\text { [55] }\end{array}$ & 2013 & $\sqrt{ }$ & & $\sqrt{ }$ & $\begin{array}{l}\text { Report of } 10 \text { students at Northwestern } \\
\text { University who performed a } 10 \text {-week rota- } \\
\text { tion in Mexico and Nicaragua; description of } \\
\text { two different exchange models }\end{array}$ & $\begin{array}{l}\text { No outcomes reported; } \\
\text { learning objectives very } \\
\text { broad (social } \\
\text { determinants of health) }\end{array}$ \\
\hline Rybak, N. [56] & 2013 & $\sqrt{ }$ & $\sqrt{ }$ & & $\begin{array}{l}\text { Description of partnerships between Brown } \\
\text { University and Haiti, and the Ukraine; } \\
\text { hosting incoming students }\end{array}$ & $\begin{array}{l}\text { Descriptive article. US } \\
\text { student involvement not } \\
\text { specifically mentioned }\end{array}$ \\
\hline $\begin{array}{l}\text { Sherman, C. B. } \\
\text { [57] }\end{array}$ & 2013 & $\sqrt{ }$ & & $\sqrt{ }$ & $\begin{array}{l}\text { Program description of Brown-Kenya ex- } \\
\text { change program }\end{array}$ & $\begin{array}{l}\text { Descriptive article, same } \\
\text { program as Sherman } \\
\text { [58] }\end{array}$ \\
\hline $\begin{array}{l}\text { Sherman, C.B. } \\
\text { [58] }\end{array}$ & 2013 & $\sqrt{ }$ & & $\sqrt{ }$ & $\begin{array}{l}\text { Student experiences from Brown-Kenya pro- } \\
\text { gram }\end{array}$ & $\begin{array}{l}\text { Descriptive article; same } \\
\text { program as Sherman } \\
{[57]}\end{array}$ \\
\hline $\begin{array}{l}\text { Kulkarni, A. } \\
\text { [44] }\end{array}$ & 2014 & & $\sqrt{ }$ & & $\begin{array}{l}\text { Report of a global health program at home, at } \\
\text { Weill-Cornell Medical School; for first-year } \\
\text { students, including exposure to immigrants } \\
\text { and minorities }\end{array}$ & $\begin{array}{l}\text { Learning outcomes via } \\
\text { students' perceptions; } \\
\text { same program as } \\
\text { Francis [43] }\end{array}$ \\
\hline $\begin{array}{l}\text { Martin, B.M. } \\
\text { [59] }\end{array}$ & 2014 & & & $\sqrt{ }$ & $\begin{array}{l}\text { Report of survey on ethics - } 21 \text { medical stu- } \\
\text { dents from Emory University who returned } \\
\text { form surgical rotation in Haiti }\end{array}$ & $\begin{array}{l}\text { Focus on one learning } \\
\text { objective (ethics) }\end{array}$ \\
\hline Bruno, D. [25] & 2015 & & $\sqrt{ }$ & $\sqrt{ }$ & $\begin{array}{l}\text { Summary report-35 years of SUNY global } \\
\text { health elective for 4th-year medical students } \\
\text { in various LMICs, with learning objectives }\end{array}$ & $\begin{array}{l}\text { One school description; } \\
\text { same program as } \\
\text { Imperato [24] }\end{array}$ \\
\hline Ip, J.Y. [60] & 2015 & & & $\sqrt{ }$ & $\begin{array}{l}\text { Brief summary of 12-medical student exchange } \\
\text { program at Brown University with LMIC } \\
\text { and HIC (Japan, Germany, Italy) }\end{array}$ & $\begin{array}{l}\text { No outcome data; } \\
\text { description only }\end{array}$ \\
\hline Moran, D. [61] & 2015 & & & $\sqrt{ }$ & $\begin{array}{l}\text { Description of the development of a student } \\
\text { driven global health program at Johns } \\
\text { Hopkins University, and creation of } \\
\text { multidisciplinary center. Student electives in } \\
\text { Pune, India }\end{array}$ & $\begin{array}{l}\text { Program description only, } \\
\text { without outcomes }\end{array}$ \\
\hline Umoren, R. [62] & 2015 & $\sqrt{ }$ & & $\sqrt{ }$ & $\begin{array}{l}\text { 24-year follow-up study on students who par- } \\
\text { ticipated in international health electives be- } \\
\text { tween Indiana University and Moi } \\
\text { University, Kenya. Long-term outcomes on } \\
\text { career choices }\end{array}$ & \\
\hline $\begin{array}{l}\text { Imperato, P.J. } \\
{[24]}\end{array}$ & 2016 & $\sqrt{ }$ & & $\sqrt{ }$ & $\begin{array}{l}\text { Summary report - } 25 \text { years of SUNY global } \\
\text { health elective for 4th-year medical students } \\
\text { in various LMIC, with learning objectives }\end{array}$ & $\begin{array}{l}\text { One school description; } \\
\text { same program as Bruno } \\
{[25]}\end{array}$ \\
\hline $\begin{array}{l}\text { Paniagua-Avila, } \\
\text { M.A. [63] }\end{array}$ & 2016 & $\sqrt{ }$ & & & $\begin{array}{l}\text { Description of partnership between University } \\
\text { of Pennsylvania and Guatemala }\end{array}$ & $\begin{array}{l}\text { Unclear to what extent } \\
\text { medical education } \\
\text { involves students }\end{array}$ \\
\hline $\begin{array}{l}\text { Rohrbaugh, R. } \\
\text { [64] }\end{array}$ & 2016 & & & $\sqrt{ }$ & $\begin{array}{l}\text { Review on bidirectional student exchanges via } \\
\text { GH programs; web based, showing that } \\
\text { exchange is mostly in one direction }\end{array}$ & LMIC focus \\
\hline $\begin{array}{l}\text { Litzelman, D.K. } \\
\text { [65] }\end{array}$ & 2017 & $\sqrt{ }$ & & $\sqrt{ }$ & $\begin{array}{l}\text { Cross-sectional study on } 137 \text { students from } \\
\text { Indiana University - to Moi University, } \\
\text { Kenya, for 2-month elective; qualitative } \\
\text { outcome study, 1989-2013 }\end{array}$ & Single school \\
\hline $\begin{array}{l}\text { Peluso, M.J. } \\
\text { [66] }\end{array}$ & 2017 & & & & $\begin{array}{l}\text { Description of a global health program for } \\
\text { medical education }\end{array}$ & \\
\hline
\end{tabular}


be utilized or recognized as vehicles for the IoME or are simply not reported in the literature.

\section{Internationalization at Home}

Several articles discussed international learning at home including descriptions of on-campus didactics. The articles were wide-ranging, including descriptions of full GH programs, individual courses, local student involvement with refugees, or preparation for travel $[19-21,24,25,28,30-33,38,41$, $43-45,47,56,61]$. Two articles were reviews on international GH programs and one an overview of international school activities. Drain [32] suggested including GH education (e.g., learning about tropical disease, different cultures) in medical school curricula and/or creating a GH track for interested students. In seven articles, pre-departure training and activities were mentioned [19, 20, 24, 25, 28, 31, 38]. In one article by Vora [38], the international student travels were part of a requirement of an at home international elective.

Furthermore, we found nine articles addressing or mentioning cultural competencies and language education as part of their international efforts at home $[21-23,30,33,36,51,55$, 61]. Of these, two are review/summary articles [36, 69]. Griswold described in two reports the involvement of medical students working at home with international refugees [21, 30] _ obtaining cultural competency through this experience.

We found a much narrower interpretation of the IoME at home than that found in the broader scholarship. Most articles focused on preparatory training for students prior to travel to a LMIC as part of a GH program and failed to report on international or intercultural learning objectives or outcomes of these programs, which medical educators agree should be specific and measurable [51].

Thus, while we found evidence for internationalization at home in the peer-reviewed articles we reviewed, it was clearly connected to GH-related student mobility programs and did not engage the majority of students.

\section{Student Mobility Programs}

Student mobility, with travel duration ranging from 1 week to several months, involved in almost all cases a low- and middle-income country (LMIC). Although it is often advocated from work in other countries [70], we found limited reporting on pre-departure training in the US $[19,20,24,25$, $28,31,38]$. Ramsey describes pre-departure training but only as a cross-reference for a program description [28].

Furthermore, we identified case reports [71], summaries [54], reviews [23, 36, 40, 64], and follow-up studies or reviews that study long-term outcomes of these international experiences [20, 24, 25, 28, 31, 40, 50, 62, 65]. The followup studies focused on effect on career choices and postgraduate international work of the graduates. At least two articles summarized reviews of GH programs [51, 54]. One article reported on the IoME not specific to GH programs [36].

Finkel [29] described the only article that addressed a focused comparative component of international healthcare systems as an educational goal for students to study while aboard.

With very few exceptions, our research demonstrated that US-focused literature regarding international experience during medical school appears limited to work contexts in the LMICs. We found limited evidence in the literature of US medical programs engaging with high-income countries (HICs) for the purpose of internationalization of the curriculum, teaching, and learning. Although historically outbound student exchanges in medical education involved the European countries [24], only five reports involved student mobility to European or Japanese HICs [25, 29, 46, 60, 67] according to our search. Vora [38] includes European countries such as Armenia and the Czech Republic. In one case, where international placements included Australia, students worked specifically with Indigenous populations in remote areas [25].

In general terms and overall, our review found a range of literature on the theme of student mobility, from individual small program reports to comprehensive reviews of large GH programs. This suggests attention to both micro and macro detail in considering the impact of $\mathrm{GH}$ programs, and a strong emphasis on mobility programs for a minority of students. The articles were published in a wide range of medical journals of relevance to various health professionals, suggesting broad interest. Some groups and institutions were represented multiple times in our pool of literature, perhaps reflecting uneven interest in these themes across US institutions.

There was a general consensus that these activities have a positive impact for student learning [36, 50].

Furthermore, most articles addressing student mobility did not go beyond students' personal perceptions of the impact of their experience on their learning, which is necessarily subjective. This may be a result of no scientific metric of international/intercultural competency being recognized by medical educators [51].

\section{Discussion}

The purpose of this review was to assess the current state of IoME in the US by looking at its presence in published scholarly work.

In today's world, and for the foreseeable future, graduates of medical programs will require international and intercultural perspectives to perform both their professional and civic duties. While scholarly research on the development of all students' international understanding and intercultural skills in professional programs of higher education has increased 
dramatically in the last 25 years, the present review of the literature on IoME in the US did not find a commensurate rise in published peer-reviewed articles or research on this topic in medical education.

A number of themes were identified characterizing the current state of scholarship regarding IoME in the US. Some of them deserve more attention going forward.

Overall, we found a focus on program descriptions in the majority of articles with few discussing research into the learning outcomes and goals achieved. The reports were classified into three main categories found in IoHE (i.e., institutional partnerships, the internationalization of medical education at home, and student mobility).

The significance of the findings of the studies reported was limited because they considered outputs from only a few medical schools and were lacking in comparative data from related professions, and/or for not having a focus on standardized goal settings and outcome research. There was little evidence of structured learning regarding differences in healthcare delivery systems between nations.

A number of missing elements and gaps in the three areas of reported activity were identified. These and some possible improvements that could be made are discussed below.

First, in relation to institutional partnerships, the authors found no descriptions of how institutional partnerships were used to facilitate peer connections between students and between faculty respectively, or how technology was used to facilitate students at home interacting with students, researchers, or professionals abroad. Only one paper reported that students connected via videoconferencing [45]. This is consistent with approaches to international partnership engagement in professional programs outside of medicine, and is recognized in the literature on internationalization of the curriculum as a lost opportunity $[1,72]$. Reports on how to build a larger global medical community using modern technology and social media led by institutional partnerships will be of utmost importance in the time to come-particularly given recent global health events. As with other areas of online education, existing technology needs to further be embedded and expanded in medical school curricula given the limited reports the study shows.

Second, the commonly described partnerships with LMICs limit students' ability to appreciate the full spectrum of healthcare systems and collaborative opportunities worldwide, and restricts them from acquainting themselves with other HICs - thus preventing them from including the "best of each world" in their future practice. A more balanced combination of partners from different areas of the world is suggested. However, the authors also advise against connecting with too many partners, given experiences shared from IoHE [8].

Third, according to the published reports reviewed, internationalization at home has not been enacted to reach its full potential in medical schools in the US. By comparison, in other disciplines and professional programs (particularly, in the social sciences), there is a stronger focus on identifying international and intercultural learning outcomes for all students, and on how to teach and assess these outcomes at home $[4,73,74]$. Given that IoME is an emerging concept in medical education, it may be that there is more evidence of internationalization at home in conference papers and institutional reports. However, scholarly work on this topic is of high importance so that educators can standardize goals, research outcomes, agree on best practices, and share ideas and work. The authors suggest that medical educational societies (e.g., the American Association of Medical Colleges, AAMC) take the lead and set the framework to encourage sharing this work.

Finally, student outbound mobility in US medical schools-representing the main theme for reports on IoME-appears to be reported when it involves the LMICs. In contrast, other industrialized countries, mainly European, more commonly report outbound student mobility and related activities in other HICs [75]. This may be due to entrenched European medical student exchange programs which have been in existence for several decades, stimulated and supported by the ERASMUS program of the European Commission [76] and others. The authors advocate increasing bilateral exchange between the US and other HIC to be more inclusive for building a global medical world.

While mobility programs are an important aspect of internationalization, they are on their own insufficient. Global estimates reflect that at most $10 \%$ of students will engage in mobility programs. Furthermore, the international literature recognizes that students from marginalized backgrounds are less likely to participate in these programs. Approaches to internationalization that focus primarily on mobility are likely to exacerbate rather than address recognized inequalities in medical education and the practice of medicine [14].

Another area that is not well researched is medical students (often from the aforementioned marginalized backgrounds) who obtain part or all of their medical training in the Caribbean and move to the US for medical practice. These students and their experiences in the LMICs provide diversity, an important component for IoME at home [77-80]. However, these students are not captured within reports about IoME. Likewise, in this report, studies on international students were not included, to focus solely on reports about offerings from US medical schools.

The authors argue that the reported approaches for student mobility as an element for IoME are insufficient and call for an internationally informed approach to IoME that focuses on all students and medical educators.

Furthermore, during a time of discussion about climate change, increasing ethical sensitivity, and sustainability of global resources, it is important to take a step back and rethink current existing formats for student mobility as a means for 
IoME. Particularly in the wake of the 2020 pandemic, medical educators need to evaluate if medical students' outbound short-term missions to the LMICs is ethical, safe, and justified, and whether goals and outcomes achieved from these missions can be acquired via other alternative routes. The authors argue that optimizing internationalization at home may be a suitable alternative and should be the focus of further research.

\section{Gaps and Limitations}

The very limited number of published articles on comparative international health systems requires further investigation. While US schools of Public Health offer these fields of study, most medical students apparently have no access to acquiring knowledge about this topic. For future collaborative international work, this information is deemed important by the authors.

Considering that medical school curricula generally leave no space for the inclusion of additional coursework, medical educators need to come to a decision regarding what is deemed necessary in the future.

Furthermore, in the US, medical educators are mostly practicing clinician-researchers with little or no international professional experience and little time for curriculum review and innovation. Unless medical educators, as a community, identify and articulate a strong need for the internationalization of medical education for all students, it is likely that it will continue to be regarded as an extracurricular, optional activity for an elite minority.

We found little connection between the IoME in the US and the broader literature on IoHE and the curriculum. Educational research is an acknowledged field of study in its own right, as is internationalization. Although $87 \%$ of US medical schools have established internationalization programs, we identified a relatively small number of peerreviewed articles on the topic over a span of nearly 20 years $[36,54]$. Lack of research and publication has a significant impact on exchange of experience, programming efforts, and quality improvement. Increased communication among US and international peers via publications and conferences can have a positive impact on medical education and is important for the future of the IoME.

The limited publication of peer-reviewed articles on the internationalization of medical education may not be a reflection of the IoME in the US occupying a low priority within the medical educator community, but the consequence of unreported programs and experiences. While clearly international options are available at most US medical schools, the lack of reporting found in this study warrants further investigation and research [36].

Considering that international programs and activities involve a significant amount of resources, an analysis of financial impact or studies on cost efficiency would appear to be important but were not easily found [24].

\section{Conclusion}

At a time of growing globalization of healthcare, the internationalization of medical education can help in improving the global healthcare world. Despite a high proportion of international offerings in US medical schools, this study demonstrates that very limited sharing of experiences via published work in this field exists. The reported literature details three areas of medical educational research consistent with research in international higher education: institutional partnerships, internationalization at home education, and student mobility. All three areas will benefit from further investigation and expansion to promote internationalization of medical education for all students. These improvements should be investigated in an interdisciplinary manner in collaboration with the longstanding field of international higher education, thus leading to the betterment of Global Health.

Acknowledgements The authors would like to thank Laura Rumbley, $\mathrm{PhD}$, at the European Association for International Education (EAIE) for her helpful discussions. Many thanks to Michael Fortgang, MD, for helpful review of the manuscript.

\section{Compliance with Ethical Standards}

Conflict of Interest The authors declare that they have no conflict of interest.

\section{References}

1. Leask B. Internationalizing the curriculum: Taylor \& Francis; 2015.

2. Altbach PG. Global perspectives on higher education: Baltimore: Johns Hopkins University Press; 2016. xvi p.

3. Clifford V. Engaging the disciplines in internationalising the curriculum in the disciplines. Int J Acad Dev. 2009;14(2):133-43.

4. Leask B, Bridge C. Comparing internationalisation of the curriculum in action across disciplines: theoretical and practical perspectives. Compare: A Journal of Comparative \& International Education. 2013;43(1):79-101.

5. Beelen J, Jones E. Redefining internationalization at home. The European Higher Education Area: Amsterdam University of Applied Sciences; 2015. p. 59-72.

6. Leask B. Using formal and informal curricula to improve interactions between home and international students. J Stud Int Educ. 2009;13(2):205-21.

7. Beelen J, Jones E. Redefining internationalization at home. In: Curaj A, Matei L, Pricopie R, Salmi J, Scott P, editors. The European higher education area: between critical reflections and future policies. Cham: Springer International Publishing; 2015. p. 59-72.

8. De Wit H. Internationalization of higher education - nine misconceptions. International Higher Education. 2011;64. 
9. Winslow C. Introduction to Public Health: Center for Disease Control; 2020 [Available from: https://www.cdc.gov/ publichealth101/public-health.html. Accessed 29 May 2020

10. Brown TM, Cueto M, Fee E. The World Health Organization and the transition from "international" to "global" public health. Am J Public Health. 2006;96(1):62-72.

11. Koplan J, Bond TC, Merson M, Reddy KS, Rodriguez MH, Sewankambo NK. Towards a common definition of global health. Lancet. 2009;373:1993-5.

12. Beaglehole R, Bonita R. What is global health? Glob Health Action. 2010;3.

13. Taylor S. 'Global health': meaning what? BMJ Global Health. 2018;3(2):e000843.

14. Tsouroufli M. Viewpoint - internationalisation of medical education: hierarchies, inequalities and future directions https:// ipedjournal.com/2015/03/30/viewpoint-internationalisation-ofmedical-education-hierarchies-inequalities-and-future-directions/. Accessed 29 May 2020

15. Hanson L. Internationalising the curriculum in health. In: Green W, Whitsed, C., editor. Critical perspectives on internationalising the curriculum in disciplines. 153-158: Springer; 2015.

16. Battat R, Seidman G, Chadi N. Global health competencies and approaches in medical education: a literature review. BMC Medical Education. 2010;10.

17. Stütz A, Green W, McAllister L, Eley D. Preparing medical graduates for an interconnected world: current practices and future possibilities for internationalizing the medical curriculum in different contexts. J Stud Int Educ. 2015;19(1):28-45.

18. Arksey H, O'Malley L. Scoping studies: towards a methodological framework. Int J Soc Res Methodol. 2005;8(1):19-32.

19. Haq C, Rothenberg D, Gjerde C. New world views: preparing physicians in training for global health work. Fam Med. 2000;32.

20. Esfandiari A, Drew CR, Wilkerson L, Gill G, Drew CR. An international health/tropical medicine elective. Acad Med. 2001;76(5): 516.

21. Griswold K. Refugee health and medical student training. Fam Med. 2003;35(9):649-54.

22. Godkin M, Savageau J. The effect of medical students' international experiences on attitudes toward serving underserved multicultural populations. Fam Med. 2003;35.

23. Thompson MJ, Huntington MK, Hunt DD, Pinsky LE, Brodie JJ. Educational effects of international health electives on U.S. and Canadian medical students and residents: a literature review. Acad Med. 2003;78.

24. Imperato PJ. A third world international health elective for U.S. medical students: the 25-year experience of the State University of New York, Downstate Medical Center. J Community Health. 2004;29(5):337-73.

25. Bruno DM, Imperato PJ. A global health elective for US medical students: the 35 year experience of the State University of New York, Downstate Medical Center, School of Public Health. J Community Health. 2015;40(2):187-98.

26. Jotkowitz AB, Gaaserud A, Gidron Y, Urkin J, Margolis CZ, Henkin Y. Evaluation of student attitudes and knowledge in a new program in international health and medicine. Medical Teacher. 2004;26(6):574-6.

27. Margolis CZ, Deckelbaum RJ, Henkin Y, Baram S, Cooper P, Alkan ML. A medical school for international health run by international partners. Acad Med. 2004;79(8):744-51.

28. Ramsey AH, Haq C, Gjerde C, Rothenberg D. Career influence of an international health experience during medical school. Fam Med. 2004;36

29. Finkel ML, Fein O. Teaching medical students about different health care systems: an international exchange program. Acad Med. 2006;81(4):388-90.
30. Griswold K, Kernan JB, Servoss TJ, Saad FG, Wagner CM, Zayas LE. Refugees and medical student training: results of a programme in primary care. Med Educ. 2006;40(7):697-703.

31. Smith JK, Weaver DB. Capturing medical students' idealism. Ann Fam Med. 2006;4 Suppl 1:S32-7 discussion S58-60.

32. Drain PK, Primack A, Hunt DD, Fawzi WW, Holmes KK, Gardner P. Global health in medical education: a call for more training and opportunities. Acad Med. 2007:82(3):226-30.

33. Houpt E, Pearson R, Hall T. Three domains of competency in global health education: recommendations for all medical students. Acad Med. 2007;82:222-5.

34. Ly EJ. Going home: lessons for a Brown medical student in Cambodia. Medicine and health, Rhode Island. 2007;90(11):352, 6.

35. Mao JJ, Wax J, Barg FK, Margo K, Walrath D. A gain in cultural competence through an international acupuncture elective. Fam Med. 2007;39(1):16-8.

36. McKinley DW, Williams SR, Norcini JJ, Anderson MB. International exchange programs and U.S. medical schools. Acad Med. 2008;83(10 Suppl):S53-7.

37. Cohn J, Friedman HM. Sustainable international partnership building for academic medical centers: experiences with the BotswanaUPenn Partnership. The Virtual Mentor. 2010;12(3):179-83.

38. Vora N, Chang M, Pandya H, Hasham A, Lazarus C. A studentinitiated and student-facilitated international health elective for preclinical medical students. Medical Education Online. 2010;15.

39. Chin-Quee A, White L, Leeds I, MacLeod J, Master VA. Medical student surgery elective in rural Haiti: a novel approach to satisfying clerkship requirements while providing surgical care to an underserved population. World J Surg. 2011;35(4):739-44.

40. Jeffrey J, Dumont RA, Kim GY, Kuo T. Effects of international health electives on medical student learning and career choice: results of a systematic literature review. Fam Med. 2011;43(1):21-8.

41. Landrigan PJ, Ripp J, Murphy RJ, Claudio L, Jao J, Hexom B, et al. New academic partnerships in global health: innovations at Mount Sinai School of Medicine. The Mount Sinai Journal of Medicine, New York. 2011;78(3):470-82.

42. Anderson H, Liebe S, Bien M. The impact of global health experiences. South Dakota Medicine. 2012;65(11):428.

43. Francis ER, Goodsmith N, Michelow M, Kulkarni A, McKenney AS, Kishore SP, et al. The global health curriculum of Weill Cornell Medical College: how one school developed a global health program. Academic Medicine. 2012;87(9):1296-302.

44. Kulkarni A, Francis ER, Clark T, Goodsmith N, Fein O. How we developed a locally focused Global Health Clinical Preceptorship at Weill Cornell Medical College. Medical Teacher. 2014;36(7):573-7.

45. Goldner BW, Bollinger RC. Global health education for medical students: new learning opportunities and strategies. Medical Teacher. 2012;34(1):e58-63.

46. Holmes D, Zayas LE, Koyfman A. Student objectives and learning experiences in a global health elective. J Community Health. 2012;37(5):927-34

47. Nelson BD, Saltzman A, Lee PT. Bridging the global health training gap: design and evaluation of a new clinical global health course at Harvard Medical School. Medical Teacher. 2012;34(1):45-51.

48. Pallangyo K, Debas HT, Lyamuya E, Loeser H, Mkony CA, O'Sullivan PS, et al. Partnering on education for health: Muhimbili University of Health and Allied Sciences and the University of California San Francisco. J Public Health Policy. 2012;33(Suppl 1):S13-22.

49. Aldan TJ, Morie M, Lee J, Withy K. Student perspectives on international/rural experiences in medical education. Hawai'i Journal of Medicine \& Public Health. 2013;72(1):23-6.

50. Cherniak WA, Drain PK, Brewer TF. Educational objectives for international medical electives: a literature review. Acad Med. 2013;88(11):1778-81. 
51. Khan OA, Guerrant R, Sanders J, Carpenter C, Spottswood M, Jones DS, et al. Global health education in U.S. medical schools. BMC Medical Education. 2013;13:3

52. Leeds IL, Hugar LA, Pettitt BJ, Srinivasan J, Master VA. International surgical clerkship rotation: perceptions and academic performance. Am J Surg. 2013;206(2):280-6.

53. O'Connell J. Practical aspects of the Kenya Medical Exchange Program. Rhode Island Medical Journal. 2013;96(9):19-20.

54. Peluso MJ, Forrestel AK, Hafler JP, Rohrbaugh RM. Structured global health programs in U.S. medical schools: a web-based review of certificates, tracks, and concentrations. Acad Med. 2013;88(1):124-30.

55. Rassiwala J, Vaduganathan M, Kupershtok M, Castillo FM, Evert J. Global health educational engagement - a tale of two models. Acad Med. 2013;88(11):1651-7.

56. Rybak N, Koster M, Gilbert EB, Flanigan T. Building international collaborations from the ground up: Brown University partnerships in Haiti and Ukraine. Rhode Island Medical Journal (2013). 2013;96(4):33-7.

57. Sherman C, Carter J. The Brown Kenya Medical Exchange Program: an overview. Rhode Island Medical Journal. 2013;96(9):14-5.

58. Sherman CB. The Medical Exchange: Brown, Moi students/ residents share their experiences. Rhode Island Medical Journal. 2013;96(9):21-4.

59. Martin BM, Love TP, Srinivasan J, Sharma J, Pettitt B, Sullivan C, et al. Designing an ethics curriculum to support global health experiences in surgery. J Surg Res. 2014;187(2):367-70.

60. Ip JY. Part II - Brown University's Program in Liberal Medical Education (PLME): Medical Exchange Programs; Student Research. Rhode Island Medical Journal (2013). 2015;98(8):14.

61. Moran D, Edwardson J, Cuneo CN, Tackett S, Aluri J, Kironji A, et al. Development of global health education at Johns Hopkins University School of Medicine: a student-driven initiative. Medical Education Online. 2015;20:28632.

62. Umoren RA, Gardner A, Stone GS, Helphinstine J, Machogu EP, Huskins JC, et al. Career choices and global health engagement: 24year follow-up of U.S. participants in the Indiana University-Moi University elective. Healthcare (Amsterdam, Netherlands). 2015;3(4):185-9.

63. Paniagua-Avila MA, Messenger E, Nelson CA, Calgua E, Barg FK, Bream KW, et al. The Guatemala-Penn Partners: an innovative inter-institutional model for scientific capacity-building, healthcare education, and public health. Front Public Health. 2017;5:70.

64. Rohrbaugh R, Kellett A, Peluso MJ. Bidirectional exchanges of medical students between institutional partners in global health clinical education programs: putting ethical principles into practice. Annals of Global Health. 2016;82(5):659-64.

65. Litzelman DK, Gardner A, Einterz RM, Owiti P, Wambui C, Huskins JC, et al. On becoming a global citizen: transformative learning through global health experiences. Annals of Global Health. 2017;83(3-4):596-604.

66. Peluso MJ, van Schalkwyk S, Kellett A, Brewer TF, Clarfield AM, Davies D, et al. Reframing undergraduate medical education in global health: rationale and key principles from the Bellagio Global Health Education Initiative. Medical Teacher. 2017:1-7.

67. Imperato PJ, Bruno DM, Sweeney MM. Ensuring the health, safety and preparedness of U.S. medical students participating in global health electives overseas. J Community Health. 2016;41(2):442-50.

68. Hudzik J. Comprehensive internationalization- from concept to action. Steiner J, editor. Washington, DC, USA: NAFSA: Association of International Educators; 2011. 44 p.

69. Khan OA, Pietroni MP, Cravioto A. Global health education: international collaboration at ICDDR. B J Health Pop Nutr. 2010;28.

70. Wallace LJ, Webb A. Pre-departure training and the social accountability of International Medical Electives. Education for Health (Abingdon, England). 2014;27(2):143-7.

71. Anderson AK, Nemecek JE, Navari RM. International study in premedical education. Acad Med. 2001;76(11):1158.

72. Helms RM. Mapping internationalization on U.S. campuses 2017. 2017.

73. Green $\mathrm{W}$, Whitsed C. Critical perspectives on internationalising the curriculum in disciplines: reflective narrative accounts from business, education and health (global perspectives on higher education) Whitsed C, editor: SensePublishers; 2015.

74. Kain VJ. Internationalisation of the curriculum in an undergraduate nursing degree. In: Green W, Whitsed C, editors. Critical perspectives on internationalising the curriculum in disciplines. Rotterdam: Sense; 2015. p. 205-18.

75. Tillmanns RW, Ringwelski A, Kretschmann J, Spangler LD, Curry RH. The profession of medicine: a joint US-German collaborative project in medical education. Medical Teacher. 2007;29(9):e269-75.

76. Williamson J. ERASMUS cultural exchanges in Europe. British Journal Of Nursing (Mark Allen Publishing). 1994;3(21):1124-8.

77. van Zanten M, Boulet JR. Medical education in the Caribbean: a longitudinal study of United States Medical Licensing Examination performance, 2000-2009. Acad Med. 2011;86(2):231-8.

78. van Zanten M, Boulet JR. Medical education in the Caribbean: quantifying the contribution of Caribbean-educated physicians to the primary care workforce in the United States. Acad Med. 2013;88(2):276-81.

79. Norcini J, Anderson MB, McKinley DW. The medical education of United States citizens who train abroad. Surgery. 2006;140(3):338-46.

80. Eckhert NL, van Zanten M. U.S.-citizen international medical graduates-a boon for the workforce? N Engl J Med. 2015;372(18):1686-7.

Publisher's Note Springer Nature remains neutral with regard to jurisdictional claims in published maps and institutional affiliations. 